\title{
Respon Penggunaan Media Power Point Berbasis Interaktif untuk Anak Usia Dini di Era Pandemi
}

\author{
Kholida Munasti ${ }^{\circledR}$, Suyadi ${ }^{1}$ \\ Pendidikan Islam Anak Usia Dini, Universitas Islam Negeri Sunan Kalijaga, Indonesia(1) \\ DOI: $\underline{10.31004 / o b s e s i . v 6 i 2.1567}$
}

\begin{abstract}
Abstrak
Pandemi Covid-19 membuat sekolah dilakukan secara online, media pembelajaran yang digunakan harus mendukung proses pembelajaran online. Penggunaan media pembelajaran yang menarik akan membuat pembelajaran menjadi menyenangkan dan interaktif, salah satunya dengan penggunaan Power Point 2013. Tujuan penelitian ini untuk memastikan keefektifan Power Point sebagai media pembelajaran interaktif di masa pandemi dengan melihat ketertarikan dan juga respon belajar yang ditimbulkan oleh anak. Penelitian dilakukan dengan metode deskriptif kualitatif, teknik analisis data dilakukan dengan mendeskripsikan seluruh kejadian dengan apa adanya saat penelitian berlangsung. Pengumpulan data diperoleh melalui observasi dan dokumentasi. Hasil penelitian mengungkapkan bahwa penggunaan Power Point di masa pandemi sangat efektif, karena: (1) Penggunaan Power Point dapat membangkitkan motivasi belajar, (2) Membuat senang dan tidak membosankan, (3) Meningkatkan antusiasme, (4) Membuat lebih mudah mengingat. Diharapkan dengan adanya penelitian ini, akan semakin banyak sekolah yang menggunakan Power Piont sebagai media pembelajaran interaktif untuk menjalin komunikasi dua arah antara guru dengan murid.
\end{abstract}

Kata Kunci: power point; media pembelajaran anak; pandemi

\begin{abstract}
The Covid-19 pandemic has made schools run online, and the learning media used must also support the online learning process. The use of exciting learning media will make learning fun and interactive, one of which is Power Point 2013. This study aims to ensure the effectiveness of Power Point as an interactive learning medium during the pandemic by looking at the interest and learning responses generated by children. This research was conducted with a qualitative descriptive method and data analysis techniques were carried out by describing all events as they were when the research took place. This research was conduct with a qualitative descriptive method, data obtained by researchers through observation and documentation. The results of the study revealed that the use of Power Point: (1) Could arouse children's learning motivation, (2) Make it fun and not boring, (3) Increase enthusiasm, (4) Makes it easier to remember. It is hoped that with this research, more schools will use Power Point as an interactive learning medium to establish good two-way communication between teachers and students.
\end{abstract}

Keywords: power point; early childhood learning media; pandemic

Copyright (c) 2021 Kholida Munasti, Suyadi

$\triangle$ Corresponding author:

Email Address : kholidamunasti@gmail.com (Yogyakarta, Indonesia)

Received 21 February 2021, Accepted 13 July 2021, Published 19 July 2021 


\section{PENDAHULUAN}

Dua tahun belakangan ini, serangan covid-19 (coronavirus disease) sangat mempengaruhi semua aktivitas manusia. Mulai dari masyarakat yang harus selalu berada di rumah dan bahkan sangat sulit berjumpa dengan orang yang disayang saat sedang berada jauh dari rumah, bekerja pun melalui rumah, serta pembelajaran daring (online) bagi para pelajar untuk memotong rantai penyebaran covid-19. Pemerintah Indonesia selalu mengusahakan sesuatu untuk membantu seluruh masyarakat agar dapat beraktivitas seperti sediakala. Di Indonesia sendiri sudah melakukan lockdown (larangan untuk pergi kemanamana), segala jenis transportasi dilarang untuk berangkat agar penyebaran virus dapat dihentikan. Namun, banyak sekali orang-orang yang mengalami kerugian dan kesulitan saat melalui masa-masa pandemi covid-19 serta tidak sedikit yang terkena PHK (Pemberhentian Hak Kerja) karena menurunnya pemasukan pada setiap perusahaan di tempat bekerja. Setelah sudah beberapa lama, pemerintah akhirnya mengubah peraturan dari lockdown menjadi Pembatasan Sosial Berskala Besar (PSBB), guna untuk memulihkan kembali kekacauan dan memperbaiki perekonomian di Indonesia. Namun aktivitas masyarakat tetap dibatasi termasuk untuk melakukan kegiatan sehari-hari seperti bekerja dan sekolah tetap dilakukan secara online. Setelah pemerintah merasa keadaan sudah mulai membaik, maka pemerintah akhirnya mengeluarkan fatwa bahwa jika ingin keluar rumah harus selalu memenuhi protokol kesehatan dengan menggunakan masker, mencuci tangan setelah bepergian dan menjaga jarak aman.

Bidang pendidikan menjadi salah satu sorotan utama yang harus mendapatkan solusi dalam pelaksanaannya karena pendidikan merupakan dasar kemajuan peradaban sebuah bangsa. Kualitas pemuda di masa depan bergantung pada produktivitas pemuda di masa sekarang. Pendidikan merupakan bagian dari sebuah kunci kesuksesan. Meskipun dalam keadaan pandemi, proses pembelajaran harus tetap berjalan. Jika sebelum pandemi pendidikan berjalan dengan baik, maka di saat pandemi seperti ini pendidikan juga harus berjalan dengan baik meskipun dengan cara dan situasi yang berbeda. Bagaimanapun juga kehadiran covid-19 ini tidak boleh memutuskan keberlangsungan pembelajaran siswa. Sehingga kegiatan belajar dan tanggungjawab mengajar guru tetap terbangun di tengah pandemi. Hal ini sejalan dengan pendapat Wibowo (2016) bahwa guru merupakan sosok pemimpin pembelajaran di sekolah yang memiliki tanggungjawab penuh atas keberadaan pembelajaran yang dilakukan. Guru harus mampu mendesain, menjalankan dan mengevaluasi praktek pembelajaran secara efektif. Sehingga dapat dikatakan bahwa guru menjadi salah satu tiang penyangga keberhasilan pendidikan sehingga guru diharuskan pandai dalam segala hal termasuk dalam menyesuaikan proses pembelajaran dengan situasi yang dialami. Secara umum menurut Sujiono \& Yuliani (2012) mengatakan bahwa pendidikan anak memiliki banyak tujuan, yaitu agar anak percaya akan Allah; mampu mengelola keterampilan anak; mampu mengembangkan bahasa dan berfikir kreatif; mampu mengenal alam dan lingkungan sekitarnya dan menghargai keberagaman budaya; mampu mengenal lingkungan sosial serta memiliki kepekaan dalam mengembangkan kreativitas yang dimiliki.

Terwujudnya pembelajaran yang berkualitas memiliki banyak faktor, salah satunya kreativitas guru dalam memberikan pengajaran baik secara tatap muka atau secara online. Menurut Cholid (2015) tuntutan guru ke depan tidaklah ringan. Terdapat 4 pilar pendidikan yang di utarakan oleh UNESCO, antara lain belajar untuk mengetahui, melakukan, berguna, dan hidup bersama. Jika di cermati, empat pilar ini menegaskan kepada seorang pendidik untuk selalu kreatif dan inovatif dalam memberikan pembelajaran. Artinya saat memutuskan untuk menjadi guru maka harus siap untuk segala keharusannya, termasuk harus pintar dalam segala hal. Menurut Adinugraha \& Hermawan (2021) ada beberapa macam kreativitas guru dalam pembelajaran, antara lain (1) Merancang dan menyiapkan bahan ajar; (2) Pengelolaan kelas yang baik; (3) Pemanfaatan waktu yang efisien; (4) Metode pembelajaran yang sesuai; (5) Media pembelajaran dan alat permainan edukatif; serta (6) Pengembangan alat evaluasi. Bahkan Simarmata et al. (2020) juga mengatakan bahwa guru harus memiliki 
beberapa keterampilan agar dapat mengajar dengan kreatif, antara lain terampil mengatur, menyajikan, bertanya, merancang, mampu mencari hubungan dan terampil dalam segala aktivitas. Sehingga dapat disimpulkan bahwa guru harus multitalenta, artinya guru mampu menjadi fasilitator yang handal dalam mendesain pembelajaran agar pesan yang disampaikan saat pembelajaran memberikan pengalaman yang berharga bagi siswa serta suasana belajar tetap hidup dan anak mendapat banyak pembelajaran yang bermakna.

Tertulis dalam Undang-Undang bahwa setiap anak berhak untuk hidup dan berkembang serta mendapatkan perlindungan hukum (UU 1945 pasal 28B ayat 2). Bahkan setiap anak di Indonesia memiliki hak untuk mendapatkan pendidikan (UU Tahun 2002 No.23 pasal 9). Pendidikan anak usia dini merupakan sebuah bagian penting dalam pencapaian tujuan pendidikan nasional. Kualitas pendidikan yang diterima akan berpengaruh kepada kemampuan seseorang (Yunianto et al., 2020). Pelaksanaan aktivitas belajar mengajar online selama pandemi merupakan hal yang sulit, karena kurangnya perlengkapan yang mendukung pembelajaran jarak jauh di sebuah sekolah serta kesiapan sumber daya yang terlibat seperti guru, siswa, dan manajemen sekolah. Menurut Adinugraha \& Hermawan (2021) pembelajaran online diartikan sebagai proses pembelajaran yang sangat bebas tanpa terikat dengan apapun, dilakukan kapan saja dan dimana saja menggunakan media sebagai penghubung guru dengan siswa. Adinugraha \& Hermawan (2021) mengatakan bahwa pembelajaran online adalah pendidikan formal yang merupakan bagian dari pembelajaran di sekolah namun dengan posisi yang berbeda sehingga membutuhkan sistem telekomunikasi interaktif untuk menghubungkannya. Sehingga dapat disimpulkan bahwa pembelajaran online merupakan pembeajaran formal seperti di sekolah namun berbasis online yang memanfaatkan teknologi telekomunikasi untuk menghubungkan guru dengan siswa sehingga pembelajaran menjadi lebih fleksibel. Pembelajaran online juga sudah didukung dengan perkembangan jaman yang telah memasuki tahap revolusi industri 4.0 yang berarti segala jenis kegiatan manusia telah didukung oleh berbagai teknologi canggih agar semua menjadi mudah baik dalam bidang ekonomi, sosial, kesehatan, kebutuhan sehari-hari dan bahkan dunia pendidikan.

Pembelajaran online disaat pandemi ini dirasa sangat membantu menjadi solusi bagi lembaga pendidikan untuk tetap mencerdaskan kehidupan bangsa dikala pandemi melanda. Pada dunia pendidikan sendiri, ada beragam aplikasi komunikasi dan presentasu yang menawarkan kemudahan untuk mengakses pengetahuan seperti Zoom Meeting, Google Meet, Power Point, Telegram, dan Whatsapp. Pembelajaran online sering dilakukan dengan mengirim pesan melalui aplikasi Whatsapp sehingga interaksi anak dengan guru hanya terbatas pada layar saja. Pendidik dituntut kreatif dalam memberikan pembelajaran dalam hal materi dan penyampaiannya baik disaat sekolah tatap muka ataupun sekolah secara online. Itulah sebabnya mengapa seorang pendidik harus kreatif, terutama pendidik di dunia anak-anak, karena sejatinya anak menyukai sebuah hal yang menarik perhatiannya. Pembelajaran online di anggap mudah dan murah karna tidak membutuhkan biaya akomodasi, para orangtua hanya membayar uang sekolah saja. Pembelajaran online membuat anak menjadi mandiri karna harus terbiasa belajar sendiri dari rumah. Namun kembali lagi jika anak sekolah itu adalah anak usia dini yang masih benar-benar membutuhkan perhatian lebih dari orang dewasa dalam mengembangkan keterampilan yang dimiliki dan tidak bisa dibiarkan belajar mandiri tanpa diawasi langsung.

Pembelajaran daring yang dilakukan saat ini sesuai dengan kemajuan dan perkembangan teknologi. Sehingga siapapun yang hidup di masa ini harus betul-betul memahami atau paling tidak mengenal berbagai media yang berkembang saat ini. Namun proses pembelajaran di rumah secara online membuat siswa menjadi jenuh dan bosan, terlebih lagi jika siswa itu adalah anak usia dini. Kustiawan (2018) memperjelas bahwa anak akan merasa bosan jika pembelajaran tidak menarik. Hal ini juga sejalan dengan hakikat anak usia dini menurut Masitoh (2011) bahwa anak penasaran dan antusias dengan hal baru; suka mengeksplorasi; daya konsentrasi singkat; serta merupakan masa emas untuk tumbuh 
kembangnya. Karakteristik pada setiap anak yang berbeda membuat perbedaan terhadap gaya belajar anak serta media yang digunakan (Fitriani et al., 2019). Gaya belajar anak menurut Priyatna (2013) meliputi pembelajar visual, auditori kinestetik dan gabungan dari keseluruhan. Penggunaan media pembelajaran sangat diperlukan terlebih dalam keadaan pandemi seperti ini supaya menghindari kebosanan yang dirasakan oleh anak saat proses pembelajaran berlangsung. Saat pembelajaran online guru biasanya hanya berbicara dan menjelaskan pembelajaran melalui pesan teks atau pesan suara yang sangat jelas membuat anak bosan dan malas belajar. Terlebih lagi, di beberapa sekolah penggunaan media pembelajaran yang mendukung sekolah online masih sangat kurang. Materi dan tugas pembelajaran hanya disampaikan melalui gambar atau foto, pesan suara atau bahkan hanya mengirimkan pesan teks melalui aplikasi Whatsapp. Media pembelajaran merupakan sarana penghubung antara guru dan siswa dalam memudahkan proses pembelajaran, terutama dalam hal komunikasi (Fitria, 2021). Ah-Sanaky (2011) menjelaskan bahwa media pembelajaran bertujuan untuk mempermudah pembelajaran di kelas, meningkatkan efisiensi pembelajaran, dan mampu meningkatkan konsentrasi belajar. Menurut penelitian Handayani dkk dikatakan bahwa pembelajaran yang masih terbatas pada buku dianggap tidak menarik dan bahkan tumpukan tugas yang diberikan saat pembelajaran online dianggap menjadi sebuah beban (Hilda Handayani, et all 2018). Dalam proses pelaksanaan pembelajaran online, guru tidak dibatasi oleh aturan termasuk media yang akan digunakan saat mengajar. Namun, pilihan media pembelajaran harus mempertimbangkan dan melihat situasi serta kondisi yang sedang terjadi sehingga proses pembelajaran dan komunikasi dua arah dapat terjalin dengan baik serta pesan yang di sampaikan dapat di mengerti.

Sangat ditegaskan sekali bahwa seorang tenaga pendidik harus mampu dan memiliki sifat yang kreatif dan inovatif, artinya pendidik harus mampu membuat peserta didiknya menjadi lebih semangat dalam pembelajaran dan juga supaya peserta didik mendapatkan pengalaman belajar yang lebih berharga. Paling tidak guru harus paham apa saja media pembelajaran yang menarik serta pengoperasiannya agar anak menjadi termotivasi belajar, apalagi di saat pandemi seperti ini. Oleh karena itu, betapa pentingnya penggunaan media pembelajaran berbasis teknologi di masa pandemi untuk menyesuaikan dengan pembelajaran yang dilakukan secara online. Pada pembelajaran online guru harus mampu menyesuaikan seluruh komponen pembelajaran, meliputi metode yang digunakan saat pembelajaran, media yang dipakai, manajemen waktu dan pemilihan teknologi yang digunakan saat pembelajaran serta kesiapan psikologis guru (Satriana et al., 2021). Maharani dkk mengatakan bahwa media yang mendukung pembelajaran secara online sangat dibutuhkan saat ini (Maharani et al., 2020). Media pembelajaran yang bisa dimanfaatkan oleh tenaga pendidik untuk hasil yang lebih menarik adalah Power Point. Sianipar (2018) bahwa Power Point dapat menyempurnakan presentasi dengan cara yang mengagumkan yang dikustomisasi dengan pilihan desain yang membantu memaksimalkan efek visual dan audio.Power Point merupakan bagian dari perangkat lunak Office. Office sendiri bukan hanya sekedar gabungan program aplikasi pengolah kata, lembar kerja, atau presentasi saja tetapi sudah lebih lengkap menjadi suatu sistem yang berinteraksi dan berkolaborasi dengan layanan berbasis web. Menurut Permana \& Pratita, 2019) Microsoft Power Point atau biasa disebut Power Point merupakan aplikasi presentasi yang membantu dalam membuat slide presentasi agar lebih menarik dan terlihat professional karena dilengkapi dengan berbagai efek, animasi dan suara. Sehingga dapat disimpulkan bahwa pembelajaran yang dikemas dalam bentuk Power Point dan dipermanis dengan penambahan gambar, efek animasi, musik dan beragam suara lainnya akan mampu menarik perhatian anak. Power Point yang disajikan untuk anak berbeda dengan yang disajikan kepada orang dewasa. Penyajian Power Point untuk anak harus memuat berbagai gambar, suara, efek animasi, dan berwarna-warni serta didesain semenarik mungkin agar anak tertarik dan antusias untuk belajar dan mengikuti pembelajaran. 
Penelitian dari Philips Parette et al. (2008) menyatakan bahwa penggunaan Power Point dapat meningkatkan kemampuan literasi anak. Pada penelitian ini hanya menggunakan Power Point yang digabung dengan instruksi secara langsung, artinya saat tampilan pada Power Point ditunjukkan, guru langsung menjelaskan dan bertanya tentang isi di dalam Power Point tersebut. Sehingga power point hanya digunakan sebagai alat menampilkan. Pada penelitian Sari et al. (2020) mengembangkan permainan digital berbasis Power Point bernama Mipon's Daily yang interaktif dengan mengangkat kegiatan anak sehari-hari yang berfokus pada pemahaman berhitung anak. Hal ini juga menjelaskan bahwa penggunaan Power Point dapat mengoptimalkan pembelajaran. Terkait hal tersebut peneliti ingin merancang sebuah pembelajaran menggunakan Power Point dan membahas tentang hewan di sekitar tempat tinggal anak. Isi di dalam Power Point memuat tentang jenis hewan, makanannya, tempat tinggalnya, bagian tubuh hewan dan mengenalkan tentang pentingnya mencintai lingkungan sekitar dan makhluk hidup di dalamnya. Tak lupa pula peneliti menambahkan games untuk membuat pembelajaran menjadi menyenangkan. peneliti menggunakan animasi, gambar, dan efek suara untuk membuat tampilan Power Point menjadi lebih menarik.

Menurut Septiana (2019) penggunaan Power Point memiliki banyak manfaat, antar lain (1) Meningkatkan kepercayaan diri, sesuai yang diketahui Power Point memiliki beragam fitur yang membantu presentasi menjadi lebih menarik dan membuat seseorang menjadi semakin percaya diri dalam menjelaskan; (2) Membantu mendesain slide menjadi lebih atraktif, Power Point memberikan hasil yang terbaik dengan fitur latar belakang, animasi dan desain yang disediakan bahkan dapat ditambahkan dengan lagu, video ataupun foto; (3) Membuat pendengar lebih focus dengan informasi yang disajikan. Power Point menampilkan kata kunci atau poin-poin dari setiap presentasi sehingga membuat pendengar lebih fokus, bahkan informasi yang disampaikan dapat berupa gambar, video ataupun suara. Ariyanti (2016) memperjelas bahwa ada beberapa prinsip pembelajaran anak, antara lain (1) Pembelajaran berorientasi pada anak, artinya anak yang harus terlibat aktif dalam pembelajaran; (2) Melalui bermain anak dapat belajar; (3) Suasana belajar yang mendukung; (4) Pembelajaran terpadu yang disesuaikan dengn tema; (5) Pembelajaran dilaksanakan dengan bertahap dan berulang; (6) Media dan sumber belajar yang beragam; dan (7) Berbasis kecakapan hidup dengan pembiasaan (Ariyanti, 2016). Terkait prinsip pembelajaran anak usia dini pada point ke 2 dan 8 , anak usia dini menyukai hal yang menarik perhatiannya dan juga mampu mengajak anak untuk bermain, serta penggunaan media pembelajaran yang menarik dapat membangkitkan gairah belajar anak.

Sejatinya, lembaga pendidikan anak usia dini merupakan pendidikan yang sangat urgent di seluruh penjuru, hal ini terbukti karena menjamurnya lembaga pendidikan anak usia dini yang didirikan baik di kota maupun di desa (Amini \& Suyadi, 2020). Hal ini juga sesuai dengan himbauan pemerintah yang mengatakan setiap satu desa harus memiliki satu lembaga pendidikan anak usia dini. Pendidikan Anak Usia Dini ialah segala macam upaya untuk membina anak dari lahir sampai enam tahun dengan pemberian stimulus yang membantu tumbuh kembang anak supaya bisa menjajaki pendidikan selanjutnya (Permendikbud 146, 2014). Usia ini merupakan momen terpenting dalam perjalanan tumbuh kembang anak yang akan mempengaruhi masa depan anak (Ulfadhilah \& Suyadi, 2021). Yus (2011) mengatakan bahwa pendidikan harus dimulai sejak dini. Menurut Cahyani dan Suyadi anak merupakan calon generasi penerus bangsa sehingga pendidikan anak usia dini harus disiapkan sebaik mungkin agar anak dapat berkembang sesuai dengan kapasitasnya (Cahyani \& Suyadi, 2019).Sehingga stimulasi yang diberikan sejak usia dini akan sangat berguna bagi kehidupan anak di masa depan. Pemberian stimulasi dapat dengan memfasilitasi berbagai keperluan yang mendukung pertumbuhan dan perkembangannya.

\section{METODOLOGI}

Peneliti ini diselesaikan dengan menggunakan metode deskriptif kualitatif. Proses pengumpulan data diperoleh dari hasil observasi dan dokumentasi. Observasi dilakukan 
dengan melihat proses pembelajaran online yang dilakukan di beberapa sekolah serta mengamati anak saat proses pembelajaran guna melihat ketertarikan dan motivasi belajar yang dialami anak melalui media pembelajaran Power Point di masa pandemi. Peneliti menggunakan aplikasi Power Point 2013. Peneliti juga melakukan dokumentasi saat anak sedang berinteraksi dengan Power Point serta mendokumentasikan slide Power Point yang disuguhkan kepada anak. Teknik analisis data dalam penelitian ini adalah dengan mendeskripsikan situasi pada setiap kejadian dengan apa adanya saat proses penelitian berlangsung. Penelitian ini dilakukan pada 12 April 2021 di Perumahan Rorinata, Medan Sunggal, Sumatera Utara pada seorang anak bernama Rafa yang berusia 4 tahun. Sulitnya bertamu kerumah masyarakat dan sulitnya mengumpulkan beberapa anak membuat peneliti hanya bisa menggunakan 1 relawan sebagai sampel untuk penelitian ini.

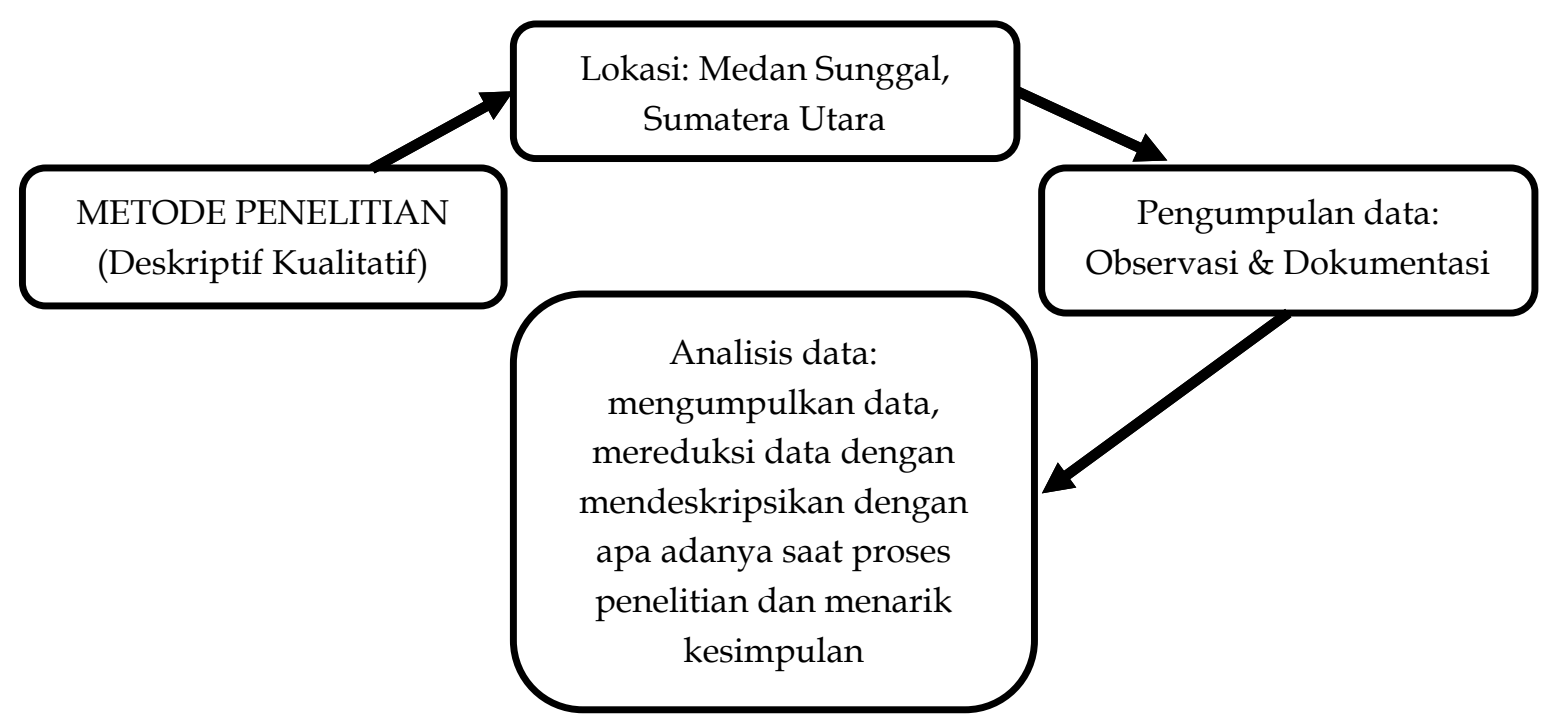

\section{Gambar 1. Ilustrasi Penelitian}

\section{HASIL DAN PEMBAHASAN}

Menurut hasil observasi ditemukan ada banyak sekolah yang tidak menjalankan sekolah online secara efektif. Hal ini disebabkan karena sebagian besar sekolah disekitar tempat penelitian hanya menggunakan aplikasi Whatsapp untuk mengirimkan tugas atau materi pembelajaran dengan pesan teks, foto, dan pesan suara aja. Begitu banyaknya teknologi komunikasi dan presentasi yang dapat digunakan pada masa sekarang ini tetapi sekolahsekolah hanya menggunakan grup Whatsapp. Inilah yang menyebabkan proses pembelajaran online dirasa kurang efektif. Penggunaan media pembelajaran yang sekarang sangat cocok digunakan di masa revolusi industri adalah Power Point, karena Power Point merupakan aplikasi presentasi yang bisa menggunakan berbagai efek dan animasi. Power Point yang peneliti gunakan adalah Power Point 2013. Penggunaan Power Point sangat membantu mengurangi kejenuhan saat belajar online. Hal ini karena Power Point menawarkan berbagai fitur canggih untuk membantu proses pembelajaran menjadi lebih seru dan menyenangkan. Power Point yang disajikan kepada anak harus dikemas dengan bagus dan menarik agar semakin memotivasi anak untuk belajar karena pada dasarnya anak menyukai segala sesuatu yang menarik perhatiannya.

Peneliti membahas tentang hewan di dalam Power Point, dan memperkenalkan berbagai jenis hewan dengan suara, makanannya, dan tempat tinggalnya. Bahkan tak lupa pula peneliti memberikan informasi bagian-bagian tubuh hewan melalui game tebak-tebakan di Power Point. Tampilan Power Point di desain semenarik mungkin dengan warna-warna yang ceria supaya anak semakin senang melihatnya. Peneliti juga menambahkan berbagai efek dan animasi yang dapat membantu setiap slide menjadi lebih menarik dan indah dilihat. Bahkan 
peneliti juga menambahkan berbagai efek suara untuk menampilkan kesan nyata pada Power Point. Tak lupa juga peneliti memberikan nilai pembelajaran karakter peduli lingkungan dengan memperkenalkan pemburu, yang mana berburu hewan itu adalah hal yang tidak baik karna membuat hewan punah.

Penggunaan animasi, perpaduan warna, serta suara menjadi daya tarik tersendiri bagi anak. Sukiyasa dan Sukoco menegaskan bahwa pelajaran yang dikmas dalam visualisasi yang menarik dan memuat animasi, gambar, dan efek suara akan lebih mudah diterima dan dipahami anak saat proses pembelajaran (Sukiyasa \& Sukoco, 2013). Hal ini terbukti ketika peneliti mulai membuka Power Point, anak langsung tertarik dan mulai banyak bertanya. Anak sangat antusias saat peneliti mulai membuka Power Point. Panjaitan juga mengatakan bahwa penggunaan media pembelajaran yang menarik akan memotivasi anak untuk belajar (Panjaitan et al., 2020). Kelebihan Power Point ialah mampu menyajikan presentasi pembelajaran menjadi lebih menarik karna dapat menampilkan gambar, animasi, dan suara secara bersamaan yang mampu membuat anak yang melihat menjadi senang dan tidak bosan. Kekurangannya ialah penggunaannya yang agak sulit bagi orang-orang yang kurang ahli dalam mengoprasikan Power Point. Prosedur pembuatan Power Point antara lain: (1) Menidentifikasi, yaitu menyesuaikan tampilan presentasi Power Point dengan penikmatnya; (2) Mengumpulkan bahan-bahan baik berupa gambar, animasi, efek suara dan musik yang bisa didapat melalui browser; (3) Susun gambar-gambar dan informasi yang sudah didapat menjadi sebuah presentasi yang menarik, dan jika sudah siap langsung presentasikan dengan menggunakan slide show. Tips membuat presentasi menggunakan Power Point menurut Nurseto, yaitu: (1) Gunakan background yang sesuai dan tidak membuat mata sakit memandang; (2) Jangan gunakan jenis huruf yang rumit; (3) Perbanyak visuallisasi gambar bukan tulisan; (4) Maksimalkan efek dan animasi namun tidak berlebihan; (5) Selaraskan warna yang digunakan baik pada tulisan ataupun background; (6) Gunakan warna-warna yang menarik; (7) Gunakan ukuran hurus yang besar agar mudah dibaca (Nurseto, 2012).
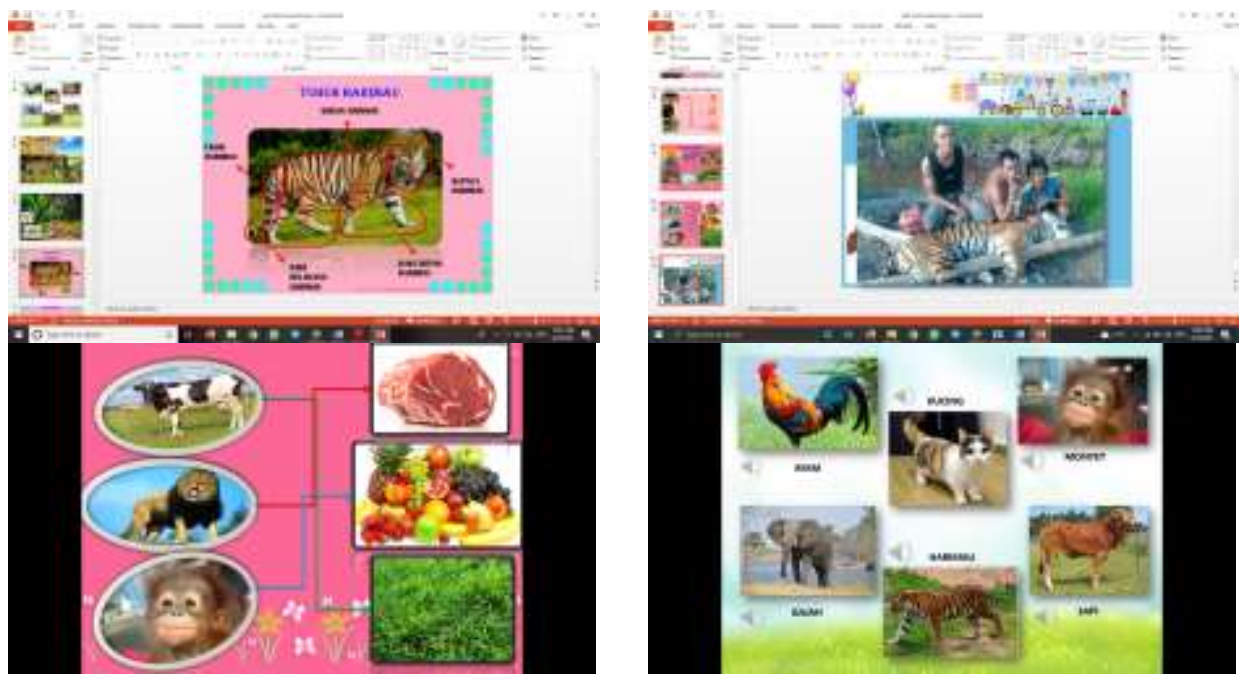

Gambar 2. Contoh isi Power Point

Wiyani (2014) menegaskan bahwa pembelajaran harus selalu mengutamakan kebutuhan setiap anak. Sejatinya anak membangun pengetahuannya sendiri, sehingga orang dewasa harus membantu memfasilitasi kebutuhan anak. Selain membuat anak menjadi antusias dan semangat belajar, penggunaan Power Point dapat membuat pembelajaran anak menjadi lebih bermakna. Hal ini terlihat dari banyaknya pertanyaan anak setelah peneliti menunjukkan Power Point. Bahkan saat penjelasan pada slide selesai anak tidak mau terburuburu pindah ke slide yang lain. Bahkan anak ingin selalu mengulang audio suara hewan berkali-kali. Anak selalu berkata "ibu cobak rafa mau tengok suara arimau (anak 
menyebutkan harimau) lagi, aaarkkkkkk (anak menirukan suara harimau)". Anak menjadi paham perbedaan suara hewan, makanannya, tempat tinggalnya dan bahkan bagian tubuhnya. Anak mampu menirukan kembali suara-suara hewan yang sudah didengar melalui Power Point. Anak juga bertanya "ibu kenak apa arimau sama ee kuceng gigi nya panjangpanjang?, ee emm". Hal ini membuktikan bahwa anak sudah menerima pembelajaran dengan baik dan mencoba menggabungkan informasi dari yang ia ketahui. Bahkan saat sudah lewat berminggu-minggu pembelajaran dengan Power Point dilakukan, anak tetap mengingat secara detail semua yang disajikan di dalam Power Point. "ibuu, emmm rafa mau tengok monyetnya lagi (diam sejenak) boleh gak?". Hal ini membuktikan bahwa penggunaan Power Point yang menarik dapat membantu ingatan anak. Bahkan, saat peneliti bertanya alasan kenapa tidak boleh membunuh hewan Rafa langsung menjawab "emm...nanti hewannya habis jadi tidak boleh di tangkap". Dari hal ini dapat disimpulkan bahwa melalui Power Point anak mendapatkan pengalaman belajar yang bermakna yang membuatnya ingat dan mengerti arti dari pembelajaran yang diberikan.
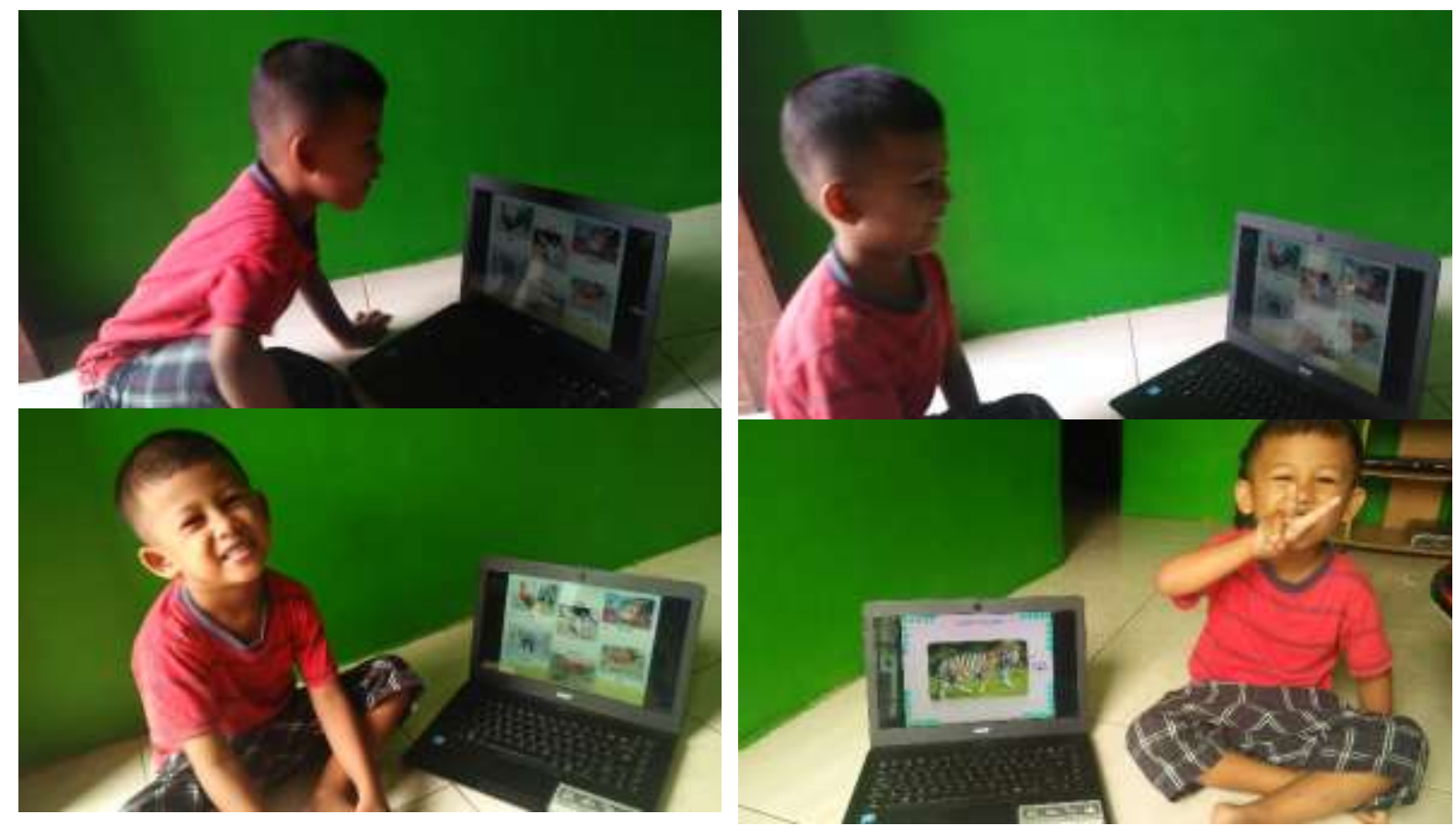

Gambar 3. Interaksi Anak dengan Power Point

\section{SIMPULAN}

Penggunaan Power Point sebagai media pembelajaran interaktif di masa pandemi sangat efektif, hal ini karena: (1) Penggunaan Power Point dapat membangkitkan motivasi belajar anak, (2) Membuat anak senang dan tidak mudah bosan, (3) membuat anak antusias dan ingin tahu lebih banyak hal, (4) Membuat anak lebih mudah mengingat pembelajaran karena Power Point menyajikan tampilan yang memadukan visual dan audio sehingga pembelajaran yang didapat anak menjadi lebih bermakna.

\section{UCAPAN TERIMA KASIH}

Alhamdulillah, puji syukur selalu peneliti ucapkan atas segala sesuatu yang telah Allah berikan. Terimakasih kepada kedua orang tua atas segala dukungan yang telah diberikan kepada peneliti, semoga semua lelahmu dan lelahku akan menjadi lillah. Terimakasih kepada orang-orang yang telah membantu proses penelitian ini hingga selesai. Semoga penelitian ini dapat memberikan banyak manfaat bagi pembaca dan peneliti selanjutnya. 


\section{DAFTAR PUSTAKA}

Adinugraha, \& Hermawan, H. (2021). Tetap Kreatif Dan Inovatif Di Tengah Pandemi Covid19. PT. Nasya Expanding Management.

Ah-Sanaky, H. (2011). Media pembelajaran buku pegangan wajib guru dan dosen. Yogyakarta: Kaukaba Dipantara.

Amini, N., \& Suyadi, S. (2020). Media Kartu Kata Bergambar Dalam Meningkatkan Kemampuan Kosakata Anak Usia Dini. PAUDIA : Jurnal Penelitian Dalam Bidang Pendidikan Anak Usia Dini, 9(2), 119-129. https://doi.org/10.26877/paudia.v9i2.6702

Ariyanti, T. (2016). Pentingnya Pendidikan Anak Usia Dini Bagi Tumbuh Kembang Anak The Importance of Childhood Education for Child Development. Dinamika Jurnal Ilmiah Pendidikan Dasar, 8(1). https:// doi.org/10.30595/DINAMIKA.V8I1.943

Cahyani, R., \& Suyadi, S. (2019). Konsep Pendidikan Anak Usia Dini Menurut Ki Hadjar Dewantara. Golden Age: Jurnal Ilmiah Tumbuh Kembang Anak Usia Dini, 3(4), 219 230. https://doi.org/10.14421/iga.2018.34-01

Cholid, N. (2015). Menjadi Guru Profesional. CV Presisi Cipta Media.

Fitria, R. A. (2021). Pengaruh Alat Permainan Edukatif Tangram dalam Meningkatkan Pemahaman Konsep Geometri di TK Qurrota A'yun Ponorogo. Aulad: Journal on Early Childhood, 4(1), 1-6. https:// doi.org/10.31004/aulad.v4i1.83

Fitriani, D., Fajriah, H., \& Rahmita, W. (2019). Media Belajar Big Book dalam Mengembangkan Kemampuan Berbahasa Reseptif Anak Usia Dini. Jurnal Obsesi : Jurnal Pendidikan Anak Usia Dini, 4(1), 247. https:// doi.org/10.31004/obsesi.v4i1.197

Hilda Handayani, Yetri, F. G. P. (2018). Pengembangan Media Pembelajaran Berbasis Macromedia Flash. Jurnal Tatsqif: Jurnal Pemikiran Dan Penelitian Pendidikan, 16(2), 87-100. https:// doi.org/10.24256/jpmipa.v1i2.95

Kustiawan, U. (2018). Children ' S Songs Creation Technique Development.

Maharani, S., Nusantara, T., As'ari, A. R., \& Qohar, A. (2020). Computational Thinking: Media Pembelajaran CSK (CT-Sheet for Kids) dalam Matematika PAUD. Jurnal Obsesi : Jurnal Pendidikan Anak Usia Dini, 5(1), 975-984. https://doi.org/10.31004/obsesi.v5i1.769

Masitoh. (2011). Strategi Pembelajaran TK. Universitas Terbuka.

Nurseto, T. (2012). Membuat Media Pembelajaran yang Menarik. Jurnal Ekonomi Dan Pendidikan, 8(1), 19-35. https:// doi.org/10.21831/jep.v8i1.706

Panjaitan, N. Q., Yetti, E., \& Nurani, Y. (2020). Pengaruh Media Pembelajaran Digital Animasi dan Kepercayaan Diri terhadap Hasil Belajar Pendidikan Agama Islam Anak. Jurnal Obsesi : Jurnal Pendidikan Anak Usia Dini, 4(2), 588. https:// doi.org/10.31004/obsesi.v4i2.404

Permana, B., \& Pratita, G. B. (2019). 36 Jam Belajar komputer Microsoft PowerPoint 2019.

Philips Parette, H., Jack J. Hourcade, Nichole M.Boeckmann, \& Craig Blum. (2008). Using microsoft PowerPoint to Support Emergent Literacy Skill Development for Young Children at-Risk or Who Have Disabilities. Early Childhood Education Journal, 36(3), 233-239. https:// doi.org/10.1007/s10643-008-0275-y

Priyatna, A. (2013). Pahami Gaya Belajar Anak: Memaksimalkan Potensi Anak dengan Modifikasi Gaya Belajar. PT Elex Media Komputindo.

Sari, N. M., Yetti, E., \& Hapidin, H. (2020). Pengembangan Media Permainan Mipon's Daily untuk Meningkatkan Kemampuan Berhitung Anak. Jurnal Obsesi : Jurnal Pendidikan Anak Usia Dini, 4(2), 831. https:// doi.org/10.31004/obsesi.v4i2.428

Satriana, M., Buhari, M. R., Makmun, M., Maghfirah, F., Haryani, W., Wahyuningsih, T., Wardana, H., Sagita, A. D. N., Oktamarina, L., \& Bakar, A. A. (2021). Persepsi Guru PAUD terhadap Pembelajaran Online: Fenomena Masa Pandemi Covid-19. Jurnal Obsesi: Jurnal Pendidikan Anak Usia Dini, 6(1), 362-373. https://doi.org/10.31004/obsesi.v6i1.1353

Septiana, N. (2019). ICT dalam Pembelajaran MI/SD. Duta Media Publishing. 
Simarmata, J., Hamid, M. A., Ramadhani, R., Chamidah, D., Simanihuruk, L., Safitri, M., Napitupulu, D., Muhammad, I., \& Salim, N. A. (2020). Pendidikan Di Era Revolusi 4.0: Tuntutan, Kompetensi \& Tantangan.

Sujiono, \& Yuliani, N. (2012). Konsep Dasar Pendidikan Anak Usia Dini. PT Indeks.

Sukiyasa, K., \& Sukoco, S. (2013). Pengaruh media animasi terhadap hasil belajar dan motivasi belajar siswa materi sistem kelistrikan otomotif. Jurnal Pendidikan Vokasi, 3(1), 126137. https:// doi.org/10.21831/jpv.v3i1.1588

Ulfadhilah, K., \& Suyadi, S. (2021). Penggunaan Media Box of Number and Alfabeth untuk Meningkatkan Kemampuan Kognitf, Bahasa dalam Mengenal Angka, dan Abjad. Aulad: Journal on Early Childhood, 4(1), 67-77. https://doi.org/10.31004/aulad.v4i1.93

Wibowo, T. G. (2016). Menjadi Guru Kreatif.

Yunianto, T., Suyadi, S., \& Suherman, S. (2020). Pembelajaran abad 21: Pengaruhnya terhadap pembentukan karakter akhlak melalui pembelajaran STAD dan PBL dalam kurikulum 2013. Premiere Educandum : Jurnal Pendidikan Dasar Dan Pembelajaran, 10(2), 203. https://doi.org/10.25273/pe.v10i2.6339

Yus, A. (2011). Model Pendidikan Anak Usia Dini (p. 114). Kencana Prenadamedia Grup. 